Fe de erratas ARQ 67

Concurso Parque Juan Pablo II, Las Condes, Santiago

En el número 67 de ARQ se omitieron algunos datos correspondientes a las autorías del proyecto para el parque Juan Pablo II, ganador del concurso convocado en 2005 por la I. Municipalidad de Las Condes. Se reproduce a continuación la ficha técnica correspondiente completa.

PARQUE JUAN PABLO II

CONCURSO, ETAPA I

Arquitectos y paisajistas Cristina Felsenhardt, Hans Mühr, Juana Zunino

Colaboradores Paula Villagra, Claudia Echeverría

DESARROLLO DEL PROYECTO, ETAPA II

Arquitectos y paisajistas Cristina Felsenhardt, Hans Mühr

Colaboradores Luis Lucero, Tomás Dalla Porta, Constanza Valenzuela

Ubicación Avda. Manquehue esq. Presidente Riesco, Las Condes, Chile

Cliente Ilustre Municipalidad de Las Condes

Materialidad edificaciones en estructura de hormigón visto y acero, terminaciones en hormigón

coloreado y pintura, parrones y glorietas en estructura de acero, terrazas sobre lagunas en estructura

de acero y terminaciones de madera tratada, senderos de hormigón coloreado y maicillo

Presupuesto sin datos

Superficie terreno $70.000 \mathrm{~m}^{2}$

Superficie proyecto $66.369 \mathrm{~m}^{2}$

Año proyecto 2000-2006

Año construcción 2007-2008

Fotografía e imágenes digitales Luis Lucero, Hans Mühr, Cristina Felsenhardt

\section{Guillermo Jullian De la Fuente} (1931-2008)

El viernes 21 de marzo de 2008 murió en Santiago el arquitecto Guillermo Jullian De la Fuente. Trabajó con Le Corbusier como jefe de taller apenas cumplidos los 27 años. Entre 1958 y 1965 el taller desarrolló un proyecto preliminar para un museo en Chandigarh y otro para el Hospital de Venecia. Su participación en ambas propuestas parece haber sido decisiva; continuó desarrollando esta última obra tras la muerte de Le Corbusier.

Realizó proyectos en Estados Unidos, Francia, España, Brasil, Madagascar, Marruecos, Irak y Argelia.

Emigró a Estados Unidos y a partir de 1987 forma el atelier Jullian-Pendleton. Se estableció en Boston por unos años. Ediciones ARQ publicó en el año 2000 el libro Guillermo Jullian / Obra abierta, del autor Rodrigo Pérez de Arce.

Hace algunos años volvió a Chile, donde dictó talleres en la Universidad Nacional Andrés Bello, la Universidad Diego Portales y la Pontificia Universidad Católica de Chile. 